\title{
Milk in Medical Theory Extant in Celsus' De medicina
}

\author{
Maciej Kokoszko ${ }^{1}$ and Jolanta Dybała ${ }^{2}$ \\ 1. Department of Byzantine History, University of Łódź, 90-136 Łódź, Poland \\ 2. University of Jan Kochanowski, 97-300 Piotrkow Trybunalski, Poland
}

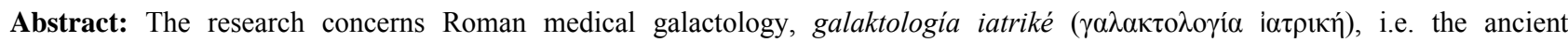
knowledge of milk and its by-products in medical procedures as described by Celsus in his treatise entitled De medicina. The authors elaborate on the sources of Celsus' medical theory of milk, comment on the place of the Roman author's theory against the doctrinal background of other medical writers of the period, demonstrate pharmacological characteristics attributed to milk and milk-obtained products by Celsus, specify main cures in which milk and its by-products were made use of as either simple or compound medicines, give examples of the latter, delineate the progress of the theory on milk's medicinal use, and finally comment on the role of milk and milk-obtained products in the diet of the Mediterranean.
\end{abstract}

Key words: Celsus, antiquity, milk, galactology, diet, medicine.

\section{Introduction}

Milk was a very significant food product in the Mediterranean [1] (and in other regions of the ancient world [2]). Thus, no wonder that ancient and Byzantine physicians devoted their time and attention to their research into dietetic and pharmacological role of the product [3]. As for its availability it is commonly believed that fresh milk was quite rare in everyday diet of antiquity [4] and the late Roman/early Byzantine period [5], whereas its derivative, namely cheese, was close to the status of a staple [6]. This general production-consumption pattern survived up to the Middle Ages [7].

The present study is not devoted to milk as such, but to (what we term) therapeutic galactology,

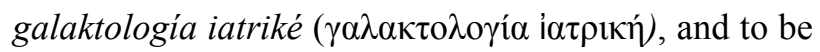
more precise to a version of it contained in De medicina penned by a Roman encyclopaedist [8] called Celsus [9] (also known as Aulus Cornelius Celsus [Aulus Cornelius Celsus]), who compiled a voluminous work consisting of most probably 26 books [6] during the reign of emperor Tiberius (14-37 AD). Out of it only 8 books (all of them devoted to

Corresponding author: Maciej Kokoszko, professor, research field: history of food in antiquity and early Byzantium. medicine) have survived [10].

The author of De medicina often reflects on the proper diet of the readers of his treatise. He compares medicine to farming already in the introduction to his work, arguing that the former provides people with health, while the latter one supplies food (Celsus, De medicina I, Prooemium 1). Diet is a capacious term for this Roman author, as he uses it to refer to a lifestyle in general, i.e. a whole set of activities practiced by human beings in their natural environment. This issue was dealt with by the branch

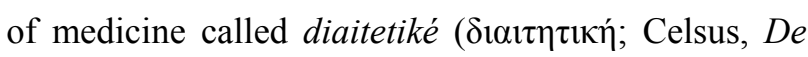
medicina I, Prooemium 9), which was further divided into speculative and empirical dietetics (Celsus, De medicinaI, Prooemium 1). Food plays a significant role in this concept, as both the amount and type of food have a significant influence on our health (Celsus, De medicina I, 2, 8-10).

Accordingly, it comes as no surprise that various types of food were described by Celsus in De medicina both in terms of their nutritional and therapeutic functions. We can infer from the narration that in the author's opinion, the latter was closely connected with the former. Such a view was a reflection of a traditional doctrine adopted by the 
Greek medicine, on whose accomplishments Celsus based his work. The very word "Greeks", meaning "Hellenic physicians", is used a few dozen times in his output [11]. Nota bene, his knowledge of Greek medical thought is also revealed in the terminology used by him, which is a Latinised jargon of the Asclepiads [12].

\section{Celsus' Doctrines Regarding Milk}

Having discussed the general aspects of Celsus' work, let us now focus on his detailed knowledge of milk and its derivatives. In order to learn about it, it is necessary to look at book II of De medicina, which contains an interesting fragment concerning procedures of cleansing the gastrointestinal tract. According to the author, in order to achieve this, enemas were used or drugs of two kinds were administered to patients, namely those that provoke cleansing through excretion and those that induce vomiting. Milk was enumerated in the first class of the second group, or, to be precise, among substances facilitating excretion. Such a laxative effect was to be achieved by animal milk, namely that obtained from donkeys, cows and goats. His narration also reveals that people would make this remedy more effective by adding some salt to it. Moreover, we learn from Celsus that milk is not a homogenous substance, but a complex one, and it is whey (referred to as serum, pó in Greek, cf. e.g. Galen, Greek physician [13], in his De alimentorum facultatibus $684,16-685,6$ ) that is the active element in the cleansing procedure. Celsus also gave us some clues with regard to the way of separating curd from the remaining liquid. According to the text, it was a result of heating milk, which caused coagulation of protein (not used during this procedure) and consequent separation of the liquid which was subsequently administered to patients (cf. Oribasius, Libri ad Eunapium I, 9, 9, 1-12, 1). The author also concluded that the cleansing procedure with the use of milk was considered safer than the use of other (more radical) remedies, so it is a good choice for patients with fever, especially considering the fact that whey not only softens the intestines, but also provides valuable nourishment (Celsus, De medicina II, 12, 1 a-c). This passage has a great educational value for a number of important clues, as it places milk and milk-derived products among therapeutic substances (namely, laxatives), indicates the methods of processing such substances, and also provides the readers with interesting details as regards the dietary and pharmacological characteristics of dairy foods.

Let us start with some basic issues. According to Celsus, milk is a combination of at least two elements which make this product a nutrient with additional properties that can be used for therapeutic purposes. It is also worth noticing that although the discussed fragment lacks precise description of milk or its components, the author in fact refers to a medical theory which established and adopted such characteristics. Celsus indicates that curd shares certain specific nutritional values with whey and that both of them contribute to the evaluation of milk as nourishing substance. We know it because the author recommends the latter as far as cleansing the digestive tract is concerned, so it can be assumed that curd has a different effect with regard to stimulating the digestive system to excrete. Therefore, it seems that Celsus suggested that it was considered by the medical specialists to be the reason for constipation. Furthermore, it should also be concluded that cheese made of curd had similar properties, as it was a derivative of the latter one. The technology described by the author of De medicina (which was supposed to show the way of obtaining whey) was in fact also a method of obtaining raw material used to produce cheese. Moreover, we may conclude on the basis of Celsus' narration that (from the point of view of pharmacological properties) cheese could not be used as a laxative, because it acquired the properties of the curd. Nota bene, one of the elements of milk was not mentioned within the analysed part of the text, but surely Celsus was aware of its existence. It was fat, 
used to produce butter (buturum/butyrum in Latin,

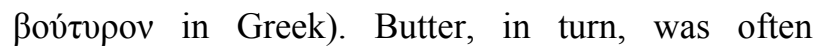
mentioned as one of therapeutic remedies and it was even described as an active substance, which means that it was in the scope of interest of pharmacology. Therefore, there is no doubt that it was addressed to by the theory acknowledged by De medicina. The analysed fragment also suggests that milk itself (as a mixture) could change its properties depending on the amount of constituents. The quantity of such elements was fully contingent on the type of milk (which is suggested by the remark about the possibility to obtain milk from various animals) and it could be modified through processing of milk. The therapeutic effect of milk could also be intensified with the use of excipients, for instance salt, as mentioned by Celsus (salt intensified the laxative effect of milk).

Far-reaching as the aforementioned conclusions may seem (in view of the general character of the analysed fragment of De medicina), they are fully confirmed in the part which discusses the role of food as a significant element of diet and which is in fact a catalogue of food groups listed according to a dominant property of a given product. It has to be indicated that medical literature of that time knows many such listings. Their fully-fledged form can be found in the works of Oribasius (firstly, in book III of Collectiones medicae, to be later included in Synopis ad Eustathium filium and in Libri ad Eunapium), then of Aetius of Amida (in book II of Iatricorum libri) and in the later treatises. We should also mention here that the dietetic characterizations composed by Celsus refer directly or indirectly to all the products mentioned here, however with the exception of butter. As we will see later, butter was characterized only from the point of view of its pharmacological properties, so it can be concluded that in the light of the medical theory adopted in De medicina it was mainly treated not as a foodstuff, but as a medicament. Such a position in the doctrine is a sign of its minimal participation in the consumption pattern of the
Mediterranean world as known to Celsus and his authorities.

Let us now present Celsus' doctrines in order of appearance in his work. The author started with emphasising the high nutritious value of milk (Celsus, De medicina II, 18, 11), and he ascribed the same property to cheese, which is conclusively confirmed by the fact that he classified baked cereal foods with the addition of animal fat, honey and cheese as wholesome diet elements (Celsus, De medicina II, 18, 2). Celsus also claimed that milk and soft (mollis, meaning fresh) cheese are evaluated as diet elements belonging to the group of food with good juices (boni suci [alimenta]; Celsus, De medicina II, 20, 1), whereas old (vetus) cheese was classified as one of the foodstuffs characterised by harmful humours (mali suci [alimenta]; Celsus, De medicina II, 21). This obviously presents Celsus as a person familiarised with the humoral theory (of some sort). Milk was also placed in the category of foodstuffs with gentle, i.e. non-pungent juices (lenes; Celsus, De medicina II, 22, 2). Apart from that, it was also indicated that this drink thickens the phlegm (crassiorem pituitam facit; Celsus, De medicina II, 23). Moreover, milk and cheese of every kind were classified as food products that may disrupt the stomach (aliena stomach; Celsus, De medicina II, 25, 1), whereas milk and all kinds of edibles to which it was added, as well as all types of cheese were considered to be a part of a group of products that get acidified easily (faciliter intus corrupta) in the stomach (Celsus, De medicina II, 28, 1). Moreover, Celsus returned to the subject that he discussed in the first analysed fragment of his work by indicating that milk and food products containing milk improve intestinal peristalsis (alvum movent), and therefore stimulate excretion (Celsus, De medicina II, 29, 2). Eventually, we also find information that cheese with pungent flavour (whether due to its age or change of properties during transport-duration of a journey was probably one of the factors contributing to the process of cheese maturing - or as a result of 
boiling it with honey or water and honey) causes constipation and slows down the activity of the digestive tract (astringit; Celsus, De medicina II, 30, 2).

Selected dairy products also appear in another catalogue. They are present as elements of respective classes of pharmacologically active substances which are listed in book V of De medicina. The catalogue of the most significant medicament groups is opened by remedies that staunch bleeding (Celsus, De medicina $\mathrm{V}, 1$ ), and concluded by effective skin cleansing substances (Celsus, De medicina V, 16). In total, there were sixteen classes of active substances enumerated by Celsus. In terms of the present discussion, it is important that even though milk and butter are present among listed medicaments, cheese and whey are not. The author does not explain the reasons for such absence in any way. It may be the case that the sources used by him did not specify these two products in the categories of our interest. Nota bene, the absence of these products does not mean that Celsus did not consider them useful for medical procedures were concerned. As it has already been explained, whey was an element of purgative diets and was referred to as lac. Cheese (also absent from the analysed list) was also taken into consideration in treatment of aphtous stomatitis, which means that it was used in the therapeutic method known to Celsus. However, such cases were rare, so this product was treated mainly as a foodstuff. It should be mentioned here that in later Greek medical sources cheese is invariably classified as phármakon. This may be proved by the testimonies to which we shall refer later in this paper. However, a conclusion can be drawn that progress in this area took place later that the state of medicine as known to Celsus was formed [14].

As far as information from De medicina is concerned, it has to be stated that milk is found among substances capable of dispersing harmful substances concentrated in any part of the body (Celsus, De medicina $\mathrm{V}, 11$; it can be effective as an anti-tumour substance). Moreover, it is listed among those medicaments that soothe irritation (together with zinc oxide, ivory etc.; Celsus, De medicina V, 13). Butter was also placed in two catalogues. First of all, we learn that it belongs to the group of medical substances causing tissue growth and filling the cavities that are formed as a result of ulcers (carnem alens; ulcus implens; Celsus, De medicina V, 14). Secondly, it is listed among the softening medicaments (molliens; Celsus, De medicina V, 15) that could eliminate tumorous calluses and swellings of all kinds. Interestingly enough, all effects of milk and butter listed above are confirmed by specific applications in treatments enumerated by Celsus. Therefore, we know that the theory to which he referred is both internally coherent and practically applicable.

Having concluded these considerations, it is necessary to pay attention to the fact that the characterizations of milk and dairy products with regard to their dietary properties and application as phármakon ( $\varphi \alpha ́ \rho \mu \kappa o v)$ are not an exclusive feature of De medicina, but they are regularly mentioned not only in medical works, such as De diaeta I-IV (milk-De diaeta I-IV 41, 4-7; whey-42, 20-22; cheese-51, 1-4; milk fat (for butter) - 51, 3), works of Dioscorides (De materia medica II, 70, 1, 1-72, 3, 9: milk-II, 70, 1, 1-3, 5; II, 70, 5, 1-6, 12; whey-II, 70, 3, 6-4, 10; cheese-II, 71, 1, 1-9; butter-II, 72, 1, 1-2, 8) [15], extant fragments penned by Rufus of Ephesus (milk: Rufus of Ephesus, De renum et vesicae morbis II, 19, 1-21, 7 and De satyriasmo et gonorrhoea 28, 5; Oribasius, Collectiones medicae II, 61, 1, 1-10, 2 and Synopsis ad Eustathium filium I, 40, 1, 1-6, 3; Aetius of Amida, Iatricorum libri II, 86, 1-87, 15; cheese: Rufus of Ephesus, De satyriasmo et gonorrhoea 28, 5) [16], Galen (De alimentorum facultatibus 681, 11-699, 9: milk, whey -681, 11-689, 7; cheese-696, 7-699, 9; butter-683, 11-684, 6 and De simplicium medicamentorum temperamentis ac facultatibus 263, 12-269, 15: milk—263, 12-269, 15; whey-266, 
7-269, 15; cheese-269, 16-272, 8; butter-272, 9-273, 18), Oribasius (Collectiones medicae II, 59, 1, 1-14, 5: milk-II, 59, 1, 1-11, 1; XV, 2, 1, 1-3, 1; whey-II, 59, 3, 2; XV, 2, 3, 1-5, 1; cheese-II, 59, 11, 1-14, 5; XV, 2, 5, 1; butter-XI, $\beta, 14,1-9$; XV, 2 , 8, 1-5) [17], Aetius of Amida (Iatricorum libri: milk-II, 86, 1-95, 28; II, 97, 1-11; whey-II, 95, 28-58; cheese-II, 101, 1-103, 7; butter-II, 104, 1-13) [18] and Paul of Aegina (Epitome: milk-VII, 3, 3, 2-11; whey-VII, 3, 3, 2-5; cheese-VII, 3, 19, 101-95; butter-VII, 3, 2, 63-66) [19], but also in Historia naturalis by Pliny (Historia naturalis XXVIII, 33, 123-36, 135: milk-XXVIII, 33, 123-130; whey-XXVIII, 33, 126-127; cheese-XXVIII, 34, 131-132; butter-XXVIII, 35, 133-134) [20]. This is a clear sign that milk was considered to be significant from the medical point of view and was as such very interesting both for the Asclepiads and for general public. It should be added here that considering all these facts, De medicina appears as a typical work, not an exceptional one. Details contained in it are simply a testimony (recorded in the first half of the 1st century) of the evolution of the doctrine that was already present in De Diaeta I-IV and later developed by the most prominent physicians.

Having proved a connection between Celsus' findings and the well-established dietetic and pharmacological doctrine, it should also be noted that De medicina contains many details regarding the role of dairy products in the feeding patterns of ancient patients as prescribed by their physicians. It should be emphasized that those practical applications of the adopted theory are not only a demonstration of the internal cohesion of Celsus' knowledge, but also relevant material for examination of the eating pattern typical of the Mediterranean up to the first half of the 1 st century. Let us now move on to the presentation of data.

Milk (without indication of its type) was for example recommended as an element of diet used in the cases of permanent loss of weight, which was a

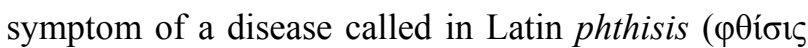
in Greek). Celsus reveals that adding milk to soups for consumptives, like for example the famous ptisáne ( $\pi \tau \iota \sigma \alpha ́ v \eta)$, called tisane [21] in the language of Cicero, to spelt flour pulp, and also to a certain starch dish (amulum/amylum in Latin, ä $\mu v \lambda \mathrm{ov}$ in Greek; Celsus, De medicina III, 22, 11) was a standard therapeutic procedure. The author also added that according to his medical knowledge milk should be completely eliminated if patients suffered from acute fever, thirst caused by an increase of body temperature, swelling of chest, bleeding or when their urine contained bile (Celsus, De medicina III, 22, 10). On the fourth or fifth day of the treatment, apart from spicy food, the patients were given a cup of broadleaf plantain (Plantago maior L.) juice or a teaspoon of white horehound (Marrubium vulgare L.) juice boiled with honey as a medicament. Terebinth resin (Pistacia terebinthus L.) cooked with butter and honey were another medicament suitable for this kind of treatment (Celsus, De medicina III, 22, 13).

Milk was also a product used in curing a condition that was manifested by difficulties with breathing. Its mildest variety was described by the Greeks as $\delta$ $\sigma \pi v o 1 \alpha$, the more severe one was called ã $\sigma \theta \mu \alpha$, whereas the most dangerous one was classified as $\rho \theta$ ó $\pi$ vora (Celsus, De medicina IV, 8, 1). The procedure recommended by Celsus included bloodletting and facilitation of intestinal cleansing through consumption of milk and, when necessary, provoking excretion through enemas (Celsus, De medicina IV, 8, 2).

Milk was also essential as a foodstuff given to patients suffering from throat ulcers (In interiore vero faucium parte exulceratio-Celsus, De medicina IV, 9, 1). In turn, food that was spicy or coarse in texture was avoided. Instead, honey, lentil, spelt wheat soup called tragum, milk, the aforementioned barley soup known as tisana, fatty meat and leek decoction were recommended (Celsus, De medicina IV, 9, 3). Cough was also a definitely very frequent condition. Several 
varieties of this ailment were distinguished (mainly productive and non-productive one) (Celsus, De medicina IV, 10, 1). Regardless of the type of this affliction, Celsus recommended travelling, especially sea journeys (aióra - a form of medical procedure) [22]. Living near the coast and swimming in the sea were also favourable. When it comes to food, the author recommended both mild and spicy products. Among the former ones, Celsus suggested consuming mallow and young nettle tips. Among the spicy ones, he listed milk cooked with garlic, soups with asafoetida (laser) or leek (cut into pieces), soft-boiled eggs with sulphur and water to drink (and then either water or wine on alternate days) (Celsus, De medicina IV, 10, 4).

On the other hand, when a patient suffered from spleen disease which was manifested by its augmentation, swelling on the left side, tension of abdomen part, oedema of the legs and other symptoms, milk and cheese (also sweets) were completely eliminated from the eating pattern (Celsus, De medicina IV, 16, 1). Instead, sour substances were recommended in such cases, especially spicy wine vinegar or vinegar with sea onion (Squilla maritima L), drunk slowly with small sips. Salted fish, olives in strong brine, salad, endive with vinegar, beetroots with mustard etc. were also prescribed, along with trotters (ungulae), chaps (rostra), non-fattened poultry (aves macrae) and game (Celsus, De medicina IV, 16, 2) [23].

The case was different when the patients experienced chronic colic. When they suffered from a condition called colitis ( which was manifested by stomachache, inability to excrete gases cumulated in the intestines, constipation, a drop in the temperature of the extremities of patient's body and difficulties with breathing (Celsus, De medicina IV, 19, 1), the pain was alleviated by warm compresses, triggering vomiting (in order to empty the stomach) and cupping therapy in the area of abdomen and hips (Celsus, De medicina IV, 19, 2). In order to provoke purgation, patients were administered milk without any additions or milk mixed with water on a one-for-one basis. One of Celsus' remarks is particularly interesting as far as the possibility to determine the intake of milk is concerned. He wrote that patients were given (probably on a daily basis) two to three cups (cyathi) of milk and, if necessary, the same amount of milk mixed with water (1:1). One cup, that is cyathus, contained 42 cubic centimetres, which equals around $0.042 \mathrm{~L}$, so four cyathi would be equal to a daily dose of milk of about $0.170 \mathrm{~L}$ (less than a standard glass). We need to remember that such an amount was prescribed for a particular case of disease (in order to provoke purgation), so it can be assumed that standard consumption was smaller. It was also believed that excretion of gases would be easier when the pressure in the intestines increases, so ground garlic was added to milk. Apart from this, $\alpha i \omega \rho \alpha$, e.g. in the form of sea journeys, rubbing with the use of olive oil with soda, cleansing with warm water, mustard plasters (which caused skin reddening, the procedure was called $\left.\sigma ı v \alpha \pi \_\mu o ́ s\right)$ applied on the limbs and many other remedies were also recommended (Celsus, De medicina IV, 19, 3).

Milk was also used in diets for the therapy of eye disorder. Celsus wrote that ulcers on eyeballs and eyelids were typical of eye inflammation. In order to eliminate them people would use enemas, go on a diet requiring limitation of food (starvation) and they also drank milk. According to the author, it was supposed to neutralise pungent juices that were responsible for the disease (Celsus, De medicina VI, 10). Milk was also mentioned with regard to the diet of patients suffering from phthirisis ( $\varphi \theta \varepsilon i p i ́ \alpha \sigma \varsigma$ in Greek). The author wrote that this ailment (usually attacking patients who did not care about hygiene) was characterized by lice appearing in the eyelashes and pus of acrid nature coming out of the eye. If the ulcers appeared on the eyeballs, the pus could even lead to loss of vision. Patients were given an enema, their hair 
was cut and their head was rubbed. Fasting, active walks, mouthwash with mulsum (boiled down with catmint and figs), warm baths and rinsing head with hot water were recommended. Food should have soothing properties. Additionally, patients were told to drink milk and sweet wine, which were supposed to neutralise the acrid character of juices that were produced during this disease (Celsus, De medicina VI, 6, 15-15 b).

De medicina also contains many tips referring to milk as a simple therapeutic substance and as an ingredient of complex medicaments. Let us start with a conclusion that Celsus' work teaches us that the medicamentum of our interest was applied both internally and externally. Accordingly, when reading De medicina, we learn that milk was considered to be an antidote, especially with regard to mild poisons. For example, it was administered (without any additions) in the case of cantharidin poisoning (cantharidin is a substance acquired from a cantharis

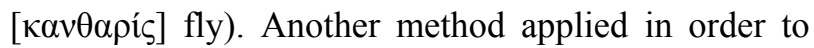
help the patient was using allheal, that is panaces (Ferula galabnifera Mill) ground with milk or administering galbanum (juice made of the aforementioned plant) dissolved in wine (Celsus, De medicina $\mathrm{V}, 27,12)$. In the case of black henbane (Hyoscyamus niger $\mathrm{L}$ ) poisoning, drinking any type of milk (but especially donkey milk) or hot wine with honey (that is mulsum; Celsus, De medicina V, 27, 12 b) [24] was recommended.

Milk was classified by Celsus as a product used as a mouthwash and gargle. The same effect was demonstrated by (probably watered-down) barley soup (tisana) and bran gruel (Celsus, De medicina V, $22,9)$. The drink of our interest in such a form was used in the final stage of tonsillitis, but bran stock could also be used for the same purpose (Celsus, De medicina VI, 10, 4). It is also worth adding that the only remark presented by Celsus with regard to therapeutic properties of cheese applies to oral cavity disorders. We learn that aphtae (aphthae in Latin, ä $\varphi \theta \iota$ in Greek) in children's mouth were removed by applying (probably fresh) cheese mixed with honey on them (Celsus, De medicina VI, 11, 3).

One of the frequent ailments described in Greek and Latin sources was dysentery. Celsus wrote that the patient suffering from this disease was supposed to rest. Special plasters that could stop diarrhoea were put on his stomach and his anus was rinsed with warm water with verbena boiled in it (Verbena officinalis L.; Celsus, De medicina IV, 22, 2). People were also given enemas in such a situation. Here, clysters made of thin tisana or milk were described by the author as effective. Moreover, melted animal fat, deer marrow, olive oil, rose oil mixed with butter (another dairy product of our interest) or egg white, as well as many other substances were introduced into the intestines (Celsus, De medicina IV, 22, 3). Themison, as Celsus accounts, even recommended using to this end the brine in which olives were kept. As for the food given to patients, it should have astringent properties (Celsus, De medicina IV, 22, 4).

In gynaecology described by Celsus, milk was used to cure hysteria. Firstly, nightshade fruits (Solanum nigrum L.) were dipped in milk and then ground with white wax or deer marrow (mixed with iris oil) or beef suet (or goat suet with rose oil) to produce ointment, which was then put as an emollient on patient's abdomen being hard as a result of the disease (super imum ventrem; Celsus, De medicina IV, 27, 1). Apart from this, the therapeutic procedure included emptying patient's intestines, which was achieved by means of giving an enema or milk (Celsus, De medicina IV, 27, 2). We also learn that woman's milk was used to produce suppositories to trigger menstruation. In order to make such a medicament, the pulp of a wild cucumber (cucumis silvestris) was ground and mixed with human milk (Celsus, De medicina $\mathrm{V}, 21 \mathrm{~b}, 1$ ), and then a piece of soft wool saturated with this substance was inserted into the genitals (Celsus, De medicina V, 21, a).

Milk was also among the substances used by 
ancient nephrology. The author of De materia medica claimed that in the case of kidney disorders, patients should rest, sleep on a soft bed, cleanse the intestines regularly (even by means of enemas), take warm baths, avoid cold food and drinks, as well as abstain from salty, sour and hot food (Celsus, De medicina IV, 17, 1). In order to cure the patient of this disease, he was given a mixture made of wild cucumber seed, pine nuts, aniseed and saffron, which were given to him with sweet mulsum wine. However, when pain appeared, an appropriate remedy made of thirty seeds of a squirting cucumber (Ecballium elaterium [L.]), twenty pine nuts, five almonds (nuces Graecae) and a bit of saffron (crocus) was administered. The ingredients were ground and then mixed with milk (Celsus, De medicina IV, 17, 2).

When it comes to external applications, Celsus reveals that joint problems (both concerning upper and lower limbs) occurring in the case of diseases such as

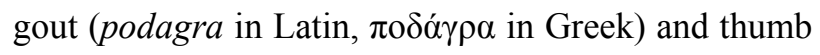
arthritis (cheragra in Latin, $\chi \varepsilon 1 \rho \alpha ́ \gamma \rho \alpha$ in Greek) were cured with the use of donkey milk treated as a sensu stricto medicament. However, it has to be concluded that this medicament was effective only in the initial phase of illness. Nota bene, the same effect was supposed to be achieved by avoiding wine, mulsum and sex (Celsus, De medicina IV, 31, 1). In the advanced stage of the disease patients were given the following recommendations: they should take a lot of exercise, visit a hot bath and ferment the sore limb in a medical solution (Celsus, De medicina IV, 31, 3-4). Sometimes a wet cooling therapy was also used, especially when the temperature of the body areas attacked by the disease was increased (Celsus, De medicina IV, 31, 5). When the pain became so strong that it was impossible to touch the place affected by the disease, it could be soothed by rinsing the affected area with a sponge dipped in hot extract of poppy-head skin or cucumis silvestris (cucumis silvestris, probably another name of squirting cucumber). Then, the place was smeared with saffron, poppy juice and sheep milk (Celsus, De medicina IV, $31,6)$. The author also added that patients who were aware of the fact that they suffer from seasonal joints ache should try to fend off this danger by a special diet and avoiding excess of dangerous substances in the food. In order to do this, they should use emetics and cleanse their intestines by drinking milk. The author of De medicina also added that the latter method was rejected by Erasistratus in fear of the risk of dangerous juices inflow into the feet in gout. However, Celsus considered the fear as unjustified and suggested that the famous physician was wrong, because the aforementioned remedies resulted in the equal removal of the juices from both upper and lower parts of the body (Celsus, De medicina IV, 31, 9).

Milk was also used as an ingredient of remedies for wounds [25]. Celsus wrote that when uncontrolled tissue growth occurred on the edges of such bodily damage, certain substances supposed to stop this phenomenon were applied. It was achieved by means of applying dry lint (siccum linamentum) or copper scales (squamae) on the affected skin area. When fungation was widespread, corossives were used. After removing the dressing, boxthorn (lycium-Rhamnus infectorius L.) decoction dissolved in passum wine or in milk was poured over the wound, which was supposed to speed up the process of scarring (Celsus, De medicina V, 26, 30 c).

Moreover, milk was an ingredient of medicaments used in ophthalmology. Celsus mentioned that woman's milk was added (in order to alleviate their effect) to eye ointments (or salves) known in Latin as

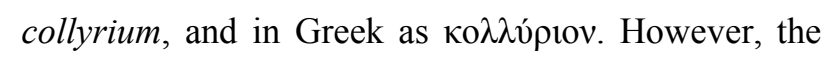
author also indicated that it was used in order to modify the salve known as cycnonor tephron (made from starch, astragalus and acacia juice, cummis gum, poppy seed juice, rinsed white lead (in Latin: cerussa; in Greek: $\psi \mu \mu \nu v 0$ tov) and lead monoxide. The ingredients were mixed together with rainwater. In the case specified by Celsus, water was replaced with breast milk-Celsus, De medicina VI, 6, 7. Galen also 
knew about this medicament-De compositione medicamentorum secundum locos 795, 4-10, and so did Aetius of Amida-Iatricorum libri (VII, 106, 75-80.) and also to another one known by the name of trygodes (made from castoreum, boxthorn, nard, poppy seed juice, saffron, myrrh, aloe, burned copper, cadmia loam, antimonite, acacia juice and cummis gum-Celsus, De medicina VI, 6, 8; they are also familiar to Galen-De compositione medicamentorum secundum locos 713, 9-10). Both those remedies were applied to the eyes in the case of moderate inflammation. Milk (without indication of the animal which gave it) was also mixed with other medicaments within the same group. Thus, in De medicina we read that in the case of acute eye inflammation called proptosis ( $\pi \rho$ ó $\pi \tau \omega \sigma \iota \varsigma$ in Greek), which was manifested by swelling that created an impression of eyeballs falling out of the orbits, when loss of vision occurred and pus was coming out of the outer corner of the eye (the one on the temple side), eyeball incision was performed. The aim of the procedure was to create an outlet for the accumulated pus, stop the pain and avoid permanent disfigurement. After the operation, Cleon's or Nileus' kollyrion was applied to the eye, but it was mixed (for the sake of alleviation of its effect) with milk (or with egg; Celsus, De medicina VI, 6, 9 b-c). Moreover, in the case of eye ulcers, Philalethes's kollyrion (myrrh, poppy seed juice, rinsed lead, loam from Samos, astragalus juice, antimony, starch, rinsed zinc oxide and white lead-Celsus, De medicina VI, 12) mixed with milk (Celsus, De medicina VI, 12) was used.

Woman's milk was added to remedies for ear inflammation, such as the medicament made of Egyptian broad beans (Nelumbium speciosum L.) ground with rose oil and myrrh or of bitter almond juice with rose oil and myrrh (Celsus, De medicina VI, 7 e). It was instilled into the auricula, which was then closed with a tampon so that the fluid could not come out (Celsus, De medicina VI, 7 c). When the ear got swollen and discharge was flowing out of it, milk (of no specified type) with boxthorn extract was poured into the ear (Celsus, De medicina VI, 7, 3 b-4). Interestingly enough, attar and milk were also used in skull surgery. The drops were supposed to help the

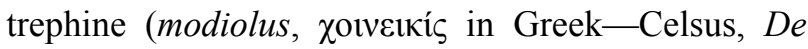
medicina VIII, 3, 1) sink into the skull bones, because the fluids reduced friction (Celsus, De medicina VIII, 3, 3) [26].

Even though cheese is mentioned rarely in $D e$ medicina, and the therapeutic applications of whey could only be guessed from the fragments concerning the purgative properties of milk, Celsus' remarks indicate that butter was an ingredient of many remedies used externally, mainly in the treatment of wounds and ulcers. For example, it was an element of

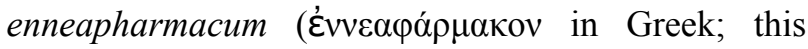
medicament was well known to Greek medics, e.g. cf. Galen, De compositione medicamentorum secundum locos 310, 15-311, 5; Oribasius, Eclogae medicamentorum 146, 17, 1-3; Aetius of Amida, Iatricorum libri XVI, 82, 16-19; Paul of Aegina, Epitome VII, 24, 6, 1-3), which was used to cleanse wounds. It consisted of wax, milk, suet, resin, myrrh, rose oil, bone marrow (deer, veal or beef), lanolin and butter mixed in equal proportions (Celsus, De medicina $\mathrm{V}, 19,10)$. Nota bene, in order to remove contamination and fill the wounds created within the tendon (after removing the pus), it was smeared with a less complex mixture, namely butter ground with rose flowers and a bit of honey (Celsus, De medicina V, 26, 30). Buturum was also referred to as an ingredient of the so-called enchrista (है $\gamma \chi \rho 1 \sigma \tau \alpha$; this term is used by e.g. Oribasius-Libri ad Eunapium III, 34, 4, 4), which were, as Celsus explained, liquid medicaments used to cure ulcers (while the Roman author referred to ulcers created on hard tissues, such as tendons, in his narration). One of the medicaments of this kind consisted of equal parts of butter, veal bone marrow, veal fat, goose schmaltz, wax, honey, terebinth, rose oil and castor oil. If the last but one ingredient was replaced with cypress oil, the medicament became 
also an emollient, so it helped with calluses (Celsus, De medicina V, 23, 3). Attention should also be paid to the fragments of Celsus' works which prove that butter was used as an ingredient of remedies for treatment of delicate and sensitive body parts (which were usually protected naturally from contact with the outer world), like for example treatment of meninx damages. The author of De medicina claimed that in order to eliminate swelling (so grave that the meninx was visible and started to come out of the wound, even beyond skull bones), ground lentil or grape vine leaves with fresh butter or goose schmaltz were applied on the area affected by the inflammation (Celsus, De medicina VIII, 4, 19).

The treatise also comprises a note that butter was suitable for genitals treatment (both in females and males). Endometritis was often cured with the use of Numenius' medicine. Its ingredients included saffron, wax, butter, goose schmaltz, boiled egg yolks and attar (Celsus, De medicina V, 21, 4). On the other hand, treatment of male penises (if ulcers on this body part were dry) consisted of rinsing the spot with warm water, and then smearing it with butter mixed with rose oil, lycium barbarum extract or amurca (amurca) mixed with wine. When the exudate appeared, ulcers were rinsed with wine, and then the area affected was covered with a mixture of butter, rose oil, honey and terebinth resin (Celsus, De medicina VI, 18, 2 c).

\section{Conclusions}

Time has come for us to draw some conclusions. The results of the analysis presented in the present discussion depict Celsus' treatise to be competent as far as galactology is concerned, that is well-set in the Greek medical thought. The results of the research have led us to the conclusion that the knowledge about milk was well developed at the moment of compiling the encyclopaedia and it did not undergo significant changes after the author's death. The successors of Celsus' authorities only added to the already existing theory. This doctrine, as physicians generally believed, assumed a double role of milk and milk-derived products, describing and using in therapeutic practice both nutritional and therapeutic functions of dairy. It was sufficiently developed to be recognized as a separate branch in both dietetics and pharmacology.

It is worth emphasizing that due to their factual content, both Celsus' treatise and other medical works containing galactological doctrine have become not only a source of the history of medicine, but also source of information concerning gastronomy, farming and breeding technologies. They also teach us about the consumption patterns of individual dairy products. Information contained in De medicina makes us think that only small amount of milk was consumed. We may also guess that this was a position of milk in the diet of educated town inhabitants to whom De medicina was addressed. They must have belonged at least to the middle class of that time, because they could afford making choices regarding food products—otherwise, Celsus' advice regarding using or rejecting particular food products in the diet recommended by him would have been irrelevant.

The data presented by Celsus show that milk that was fresh (as required by the physician) was hard to obtain. We learn it from the remark stating that milk easily curdled while it was heated. Therefore, it is no wonder that we usually encounter this partly spoilt (meaning fermented) product described as food belonging to the group of products that easily acidify in the stomach and have purgative properties. Another explanation of purgative effectiveness of milk is lactose intolerance displayed by ancient inhabitants of the Mediterranean.

The dietetic characterizations quoted here also indicate that some methods of extending the useful life of milk were applied, like adding salt to it or heating it. Let us add that fresh milk was easy to obtain in the countryside, but it was more difficult to acquire it in the towns, where most patients cured by the physicians listed by Celsus lived.

The following animals were described as giving 
milk: donkeys [27], sheep and cows [28]. Donkeys, used mainly for transportation purposes, gave little milk, so it could be used primarily for specialist therapies. Its qualities as food were also not valued. Galen described it as watery and almost deprived of fat, which implied that it hardly had any nutritional value from the point of view of dietetics. The case was different with sheep and cow milk, which was highly evaluated as food (Galen, De alimentorum facultatibus 681, 11-682, 2 (thickness of milk and the species of animals from which it was obtained; donkey milk-682, 1; sheep milk—682, 2; cow milk-681, 14); 684, 7-9 (fat content in milk and the species of animals from which it was obtained; donkey milk-684, 9; sheep milk-684, 8; cow milk-684, 7)). It can also be assumed that the opinions of the physician from Pergamon were connected with the preferences of milk consumers, and therefore with the market availability of this product. If this was the case, sheep and cow milk was much more popular than that obtained from donkeys.

When it comes to butter, it did not play a significant dietary role. It is confirmed not only by the factual content of De medicina, but also by the fact that Galen did not describe it in detail in De alimentorum facultatibus (which was his most important diet-related work), but in De simplicium medicamentorum temperamentis ac facultatibus (which is a treatise devoted to simple medicaments) and he referred to it simply as phármakon. On the other hand, Pliny wrote that it was commonly consumed among Barbarians and appreciated by them (Pliny, Historia naturalis XXIII, 35, 133). Such a statement implies not so much the strangeness of this product in the Mediterranean region, as more limited interest in this product in the Roman world (due to the preferences of the people towards olive oil).

Celsus provides us with more detail concerning the role of cheese, consumed both in its fresh (short-lasting) and mature (long-lasting) form. The latter was suitable for transport, and therefore it could be carried to distant places. It can be assumed that export was cost-effective only in the case of products that could be sold for an appropriate (high) price. Therefore, we expect that the common types of cheese were already known before the moment when $D e$ medicina treatise was written down. They were produced in accordance with the established recipes and found consumers even in the distant places. Celsus' reflections also reveal that cheese was a subject of culinary interest. At the same time, data concerning cooking cheese indicate various methods used in order to modify its taste.

Due to the fact that galactology described in $D e$ medicina was formed before the 1 st century $\mathrm{AD}$, this branch of medicine gives us an insight into the food consumed until that time. The works of Galen, who as a bright observer of life verified with his own experience the theories that reached him from his sources, can also be perceived as the witnesses of those times. When talking about the raw material from which the butter is obtained, he even dared to argue with the authority in the field of materia medica, namely Dioscorides (whose other theories he usually respected). He was surprised that the physician from Anazarbus suggested that butter should be obtained from sheep and goat milk, while he knew it was obtained from cow milk as well, and the name comes from the noun boús (ßoũs) - Galen, De simplicium medicamentorum temperamentis ac facultatibus 272, 12-15. Cf. Dioscorides, De materia medica II, 72, 1, 2-3. Starting from Oribasius, we encounter only repetitions of the established dietetic and pharmacological doctrines regarding milk. This fact questions the credibility of the medical treatises as sources regarding the period contemporary with their authors. However, it is possible that he, as well as Aetius of Amida and Paul of Aegina, wrote down classic doctrines, because changes of the range of available food products and methods of their production were rare or did not happen at all. If so, then the physicians of the early Byzantine Empire 
simply chose and passed to the next generations such elements of the theory that they considered suitable for their own medical practice.

Eventually, it has to be emphasized that both Celsus' treatise and other medical sources give us a valuable insight into different details of the diet than applications of milk and milk-derived products. Interestingly enough, there are no remarks regarding luxury spices or exotic products in the tips found in De medicina (in the context of milk and milk-derived products). Thus, it is probable that the diet-related details contained there reflect the consumption pattern characteristic for lower and middle social classes. Therefore, Celsus' treatise is a perfect reference to be used in studies concerning daily life of a broad range of the society.

\section{References}

[1] Dalby, A. 2003. Food in the Ancient World from A to Z. London-New York, 217-8.

[2] Batmanglij, N. 2000. "Milk and Its By-products in Ancient Persia and Modern Iran." In: Milk. Beyond the Dairy. Proceedings of the Oxford Symposium on Food and Cookery, 1999, 64-73.

[3] Kokoszko, M. 2015. “Galen's Therapeutic Galactology

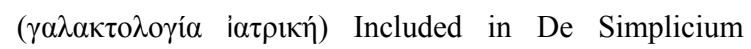
Medicamentorum Temperamentis Ac Facultatibus." Przeglad Nauk Historycznych 14 (2): 5-23 (in Polish).

[4] Wilkins, J. M., and Hill, Sh. 2006. Food in the Ancient World. Malden-Oxford, 162.

[5] Kokoszko, M. 2011. "Tastes of Constantinople." In: Constantinople-New Rome. The City and the People in the Early Byzantine Period, edited by Leszka, M. J., and Wolińska, T. Warszawa, 560-2 (in Polish).

[6] Alcock, J. P. 2006. Food in the Ancient World. Westport-London, 82.

[7] Kokoszko, M. 2011. "The Role of Dairy Products in the Diet of the Late Antiquity and Early Byzantine Period (4th-7th Century)." Zeszyty Wiejskie16: 8-28 (in Polish).

[8] Nutton, V. 2013. Ancient Medicine, London-New York, 5.

[9] Schultze, C. F. 1999. Aulus Cornelius Celsus-Arzt oder Laie? Autor, Konzept und Adressaten der De medicina libri octo. Trier, passim.

[10] Marx, F. 1915. "Prolegomena." In: A. Cornelii Celsi quae supersunt, edited by Marx, F. Lipsiae-Berlini, I-XXV.

[11] Deuse, W. 1993. "Celsus im Prooemium von 'De medicina': Römische Aneignung griechischer
Wissenschaft." In: Aufstieg und Niedergang der römischen Welt. Geschichte und Kultur Roms in Spiegel der neuern Forschung, edited by Haase, W., Vol. II, Bd. 37, 1, Berlin-New York, 819-41.

[12] Langslow, D. R. 1994. "Celsus and the Makings of a Latin Medical Terminology." In: La Médecine de Celse. Aspects historiques, scientifique, and litéraires, Mémoires du Centre Jean Palerne, vol. XIII, edited by Sabbah, G., and Mudry, P. Saint-Étienne, 297-318.

[13] Hankinson, R. J. 2008. "The Man and His Work." In: The Cambridge Companion to Galen, edited by Hankinson, R. J. Cambridge, 1-33.

[14] Chrone, M. 2014. Fauna in Nutrition and Medicinal Use in Byzantium. Athens, 217-26 (in Greek).

[15] Riddle, J. M. 1985. Dioscurides on Pharmacy and Medicine. Austin, passim.

[16] Sideras, A. 1977. "Einleitung." In: Rufus Ephesius, De renum et vesicae morbis, edited by Sideras, A. Berlin, 58-69.

[17] Jagusiak, K., and Kokoszko, M. 2011. "The Life and Career of Oribasius in the Light of Sources." Przeglad Nauk Historycznych 10 (1): 5-21 (in Polish).

[18] Nutton, V. 1984. "From Galen to Alexander. Aspects of Medicine and Medical Practice in Late Antiquity." Dumbarton Oaks Papers 38: 1-14.

[19] Pormann, P. 2004. The Oriental Tradition of Paul of Aegina's Pragmateia. Leiden, passim.

[20] Healy, J. F. 2000. Pliny the Elder on Science and Technology. Oxford, passim.

[21] Kokoszko, M., Jagusiak, K., and Rzeźnicka, Z. 2013. “A Short Commentary on the Soup Called Ptisane

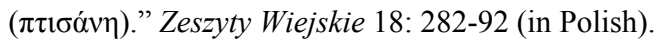

[22] Kokoszko, M. 2006. "Byzantine Medicine on aiora

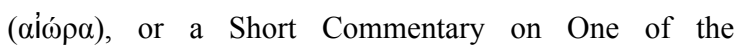
Therapeutic Methods Used in the Treatment of the Emperor Alexius I Comnenos (on the Basis of the Writings of Galen, Oribasius, Aetius of Amida and Paul of Aegina)." In: The Byzantine Empire. History-Religion-Culture. Studies Offered to Professor Waldemar Ceran by His Students on the Occasion of 70th Birthday. Edited by Krupczyński, P., and Leszka, M. J. Łask-Łódź, 87-111 (in Polish).

[23] Albala, K. 2000. "Milk: Nutritious and Dangerous" In: Milk. Beyond the Dairy. Proceedings of the Oxford Symposium on Food and Cookery 1999, 19-30.

[24] Touwaide, A. 1994. "La toxicologie dans le De medicina: un système asclépiado-méthodique?" In: La Médecine de Celse. Aspects historiques, scientifique, and litéraires, Mémoires du Centre Jean Palerne, vol. XIII, edited by Sabbah, G., and Mudry, P. Saint-Étienne, 211-56.

[25] Israelowich, I. 2015. Patients and Healers in the High Roman Empire. Baltimore, 96-7. 
[26] Mazzini, I. 1994. "La chirurgia celsiana nella storia della chirurgia greco-romana." In: La Médecine de Celse. Aspects historiques, scientifique, and litéraires, Mémoires du Centre Jean Palerne, vol. XIII, edited by Sabbah, G., and Mudry, P. Saint-Étienne, 135-66.

[27] Chrone, M. 2014. Fauna in Nutrition and Medicinal Use in Byzantium. Athens, 90-1, 362, 395 (in Greek).
[28] Rzeźnicka, Z. 2014. "The Role of Meat in the Diet between the 2nd and 7th Centuries in the Light of Medical Sources." In Dietetics and Culinary Art of Antiquity and Early Byzantium (2nd-7th c.), Part I, Cereals and Cereal Products in Medical Sources of Antiquity and Early Byzantium (2nd-7th c.). Łódź, 249-57, 266-79 (in Polish). 